\title{
Effects of seasonal variation in temperature and cultivar on yield and yield determination of irrigated groundnut (Arachis hypogaea) during the dry season in the Sahel of West Africa
}

\author{
B. R. NTARE, J.H. WILLIAMS* AND B.J. NDUNGURU† \\ ICRISAT Sahelian Center, BP 1204, Niamey, Niger \\ (Revised MS received 8 April 1998)
}

\begin{abstract}
SUMMAR Y
In the Sudano-Sahelian zone of West Africa there is potential for groundnut (Arachis hypogaea L.) to be grown as a dry-season crop where irrigation is available. However, there are substantial variations in the temperatures during the post-rainy season that can be expected to influence growth and yield. An experiment at the ICRISAT Sahelian Centre was done in order to study the effect of sowing date on phenology, yield and the processes of yield determination for four groundnut cultivars under irrigation in the dry seasons of 1990/91 and 1991/92. Starting on 15 November, eight sowing dates at 2-weekly intervals were tested. Sowing date significantly affected phenology (time to emergence, flowering and maturity) with groundnut sown in November/December taking the longest time to reach these phenological stages. November and December sowings gave the highest pod yield within each year, despite the lowest crop growth rates $(B)$, and yield declined progressively as sowing occurred later ( $50 \%$ decrease by March) despite increasing $B$. The observed responses appear to have been due to the effect of temperature differences during the pod-filling phase on partitioning. Partitioning $(p)$ to pods was optimized at $c .30 \mathrm{C}$, with some indication of cultivar differences in partitioning response to temperature. Across all the environments, cultivars displayed substantial differences in yield stability. When sown late, yields were low and lines with high partitioning were the best. When sown early in the post-rainy season, cultivars with a high $B$ value were the better choices. Plant habit differences and $B$ suggest that radiation interception was a limitation to yield, particularly when the crops were sown in the cool months of the year. However, haulm yield and crop growth rates were not consistently affected by sowing date across the years, and cultivars demonstrated different degrees of stability for $B$. It is concluded that where pod has a price advantage over fodder, irrigated groundnut for the dry season should be sown in November to allow the crop to develop under the relatively cool temperatures that maximize pod yield. Further agronomic research is suggested to maximize $B$ for individual cultivars for given sowing dates.
\end{abstract}

\section{INTRODUCTION}

Groundnut is usually grown in the Sudano-Sahelian zone of West Africa only as a rainfed crop. The rainy season is short, permitting only one crop per year. However, there is potential for groundnut to be grown as a dry-season crop where irrigation is

* Present Address: Peanut CRSP, Georgia Experiment Station, Griffin, GA 30223-1790, USA. To whom all correspondence should be addressed. Email: crspgrf@gaes.griffin.peachnet.edu

$\dagger$ Present Address: SACCAR, Post Bag 00108, Gaberone, Botswana. possible, such as in the Niger and Senegal river basins. The dry season is characterized by a cool, dry period between November and February, when temperatures are below optimum for groundnut, followed by a rapid transition to a hot, dry period when temperatures are above optimum until June. Groundnut is sensitive to temperature, with the optimum temperature for most processes being between 27 and $30{ }^{\circ} \mathrm{C}$ (De Beer 1963). Thus in the post-rainy Sahelian environment, depending on the sowing date and its phenology, a cultivar may experience sub-optimal or supra-optimal temperatures, or indeed both conditions. Both low and high temperatures are known to affect the growth and development of groundnut 
Table 1. Rainfall ( $\mathrm{mm})$, relative humidity (\%), pan evaporation $\left(\mathrm{mm}\right.$ day $\left.{ }^{-1}\right)$, and radiation $\left(M J \mathrm{~m}^{-2} d^{-1}\right)$ at the ICRISAT Sahelian Centre in Niger, West Africa during experiments in 1990/91 and 1991/92

\begin{tabular}{lcccc}
\hline \hline Month & Rainfall & $\begin{array}{c}\text { Mean relative } \\
\text { humidity }\end{array}$ & $\begin{array}{c}\text { Pan } \\
\text { evaporation }\end{array}$ & Radiation \\
\hline Nov & 0 & $1990 / 91$ & & \\
Dec & 0 & 15 & $7 \cdot 1$ & $17 \cdot 8$ \\
Jan & 0 & 12 & $7 \cdot 9$ & $15 \cdot 9$ \\
Feb & 0 & 9 & $8 \cdot 4$ & $17 \cdot 7$ \\
Mar & 8 & 14 & $10 \cdot 5$ & $18 \cdot 6$ \\
Apr & 14 & 23 & $9 \cdot 3$ & $19 \cdot 5$ \\
May & 94 & 49 & $6 \cdot 5$ & $19 \cdot 2$ \\
Jun & 121 & 52 & $6 \cdot 3$ & $21 \cdot 6$ \\
& & $1991 / 92$ & & \\
Nov & 0 & 11 & $7 \cdot 1$ & $20 \cdot 8$ \\
Dec & 0 & 15 & $6 \cdot 6$ & $20 \cdot 4$ \\
Jan & 0 & 18 & $7 \cdot 4$ & $18 \cdot 6$ \\
Feb & 0 & 10 & $9 \cdot 7$ & $23 \cdot 1$ \\
Mar & 0 & 11 & $10 \cdot 2$ & $22 \cdot 0$ \\
Apr & 12 & 18 & $9 \cdot 8$ & $22 \cdot 9$ \\
May & 44 & 38 & $8 \cdot 4$ & $22 \cdot 2$ \\
Jun & 85 & 47 & $8 \cdot 0$ & $23 \cdot 1$ \\
\hline \hline
\end{tabular}

(Bell et al. 1991a,b). Groundnut cultivars with different temperature adaptation are known (Williams et al. 1978). However, little is known about adaptation to temperature variations across phases of development.
The yield of any crop can be defined by a simple physiological model (Duncan et al. 1978):

$$
Y=B \times D_{\mathrm{r}} \times p
$$

where $Y=$ pod yield; $B=$ mean crop growth; $D_{\mathrm{r}}$ $=$ duration of the reproductive phase; and $p=\mathrm{a}$ partitioning coefficient of $B$ to reproductive structures. Variations in $B$ are dominated by light interception (Duncan et al. 1978; Monteith 1990), while variations in $D_{\mathrm{r}}$ are determined largely by temperature (Ong 1986), and $p$ by cultivar and cultivar $\times$ environment interactions (Duncan et al. 1978; Williams 1992).

In the present study the yields, individual parameters of the growth model (Eqn 1), and the phenology of four contrasting groundnut cultivars when sown on eight dates under irrigation were examined in order to detect the most appropriate period for sowing groundnut in the dry season. Such information will be useful in guiding further research, in developing management strategies that can enable the use of the long dry season for groundnut production, and will provide useful information for model development.

\section{MATERIALS AND METHODS}

The experiment was conducted during two seasons (1990/91 and 1991/92) at the International Crops Research Institute for the Semi-Arid Tropics (ICRISAT) Sahelian Centre Research Farm, $45 \mathrm{~km}$ south of Niamey, Niger $\left(13^{\circ} \mathrm{N}, 2^{\circ} \mathrm{E}\right)$. The soil is sandy (Psammentic paleostalf) with a very low water-
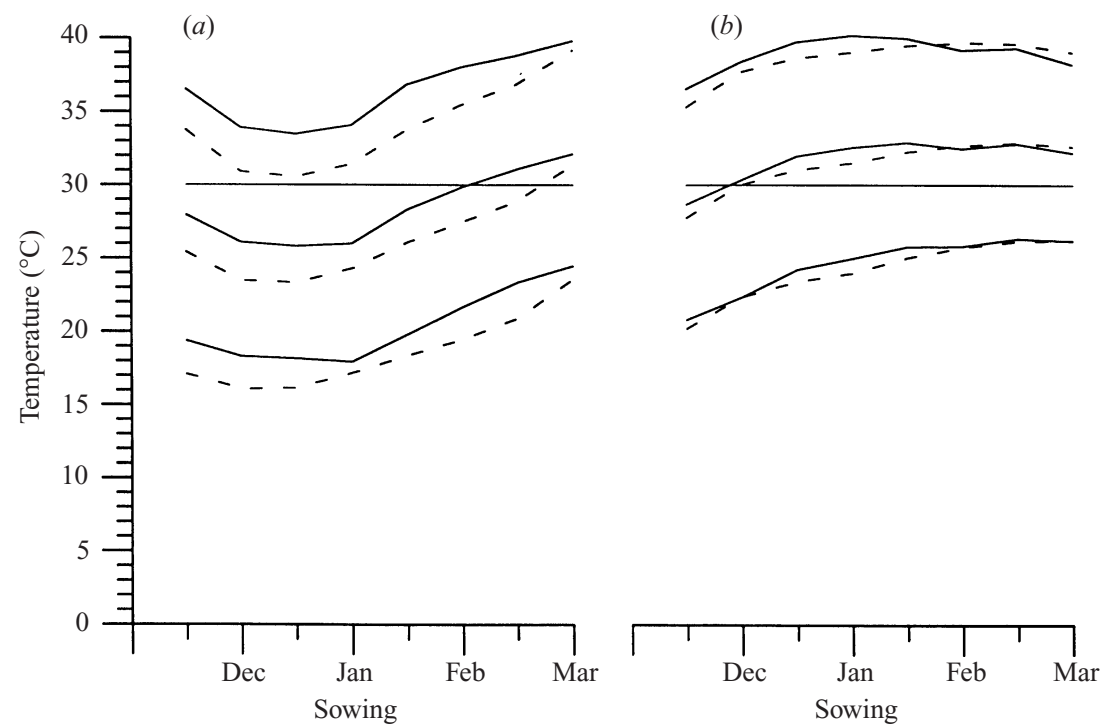

Fig. 1. Mean, minimum and maximum temperatures relative to the optimum for groundnut growth during $(a)$ vegetative and (b) reproductive phases of growth as determined by sowing date at Sadore, Niger; 1990/91 (-) and 1991/92 (---). 
Table 2. Effect of sowing date on days to $50 \%$ flowering (calendar and physiological days) of four groundnut cultivars sown at Sadore, Niger in 1990/91 and 1991/1992. Physiological days are the estimated thermal time equivalent of $24 \mathrm{~h}$ at optimum temperature $\left(30^{\circ} \mathrm{C}\right)$

\begin{tabular}{|c|c|c|c|c|c|c|}
\hline \multirow[b]{2}{*}{ Sowing date } & \multicolumn{4}{|c|}{ Cultivar (calendar days) } & \multirow{2}{*}{$\begin{array}{l}\text { Means } \\
\text { for dates }\end{array}$} & \multirow{2}{*}{$\begin{array}{l}\text { Physiological } \\
\text { days }\end{array}$} \\
\hline & $47-16$ & $55-437$ & $28-206$ & ICGS11 & & \\
\hline \multicolumn{7}{|l|}{$1990 / 91$} \\
\hline 15 Nov & 41 & 37 & 43 & 39 & 40 & $36 \cdot 2$ \\
\hline $30 \mathrm{Nov}$ & 51 & 40 & 48 & 44 & 45 & $36 \cdot 3$ \\
\hline $15 \mathrm{Dec}$ & 52 & 43 & 54 & 43 & 48 & $36 \cdot 9$ \\
\hline $30 \mathrm{Dec}$ & * & 43 & 47 & 44 & 45 & $34 \cdot 6$ \\
\hline $15 \mathrm{Jan}$ & 41 & 38 & 44 & 39 & 40 & $37 \cdot 0$ \\
\hline $30 \mathrm{Jan}$ & 34 & 33 & 39 & 33 & 35 & $35 \cdot 3$ \\
\hline $15 \mathrm{Feb}$ & 37 & 32 & 37 & 31 & 34 & $37 \cdot 6$ \\
\hline $2 \mathrm{Mar}$ & 34 & 30 & 34 & 31 & 32 & $37 \cdot 0$ \\
\hline Mean (cultivars) & 43 & 37 & 43 & 37 & & \\
\hline \multicolumn{7}{|c|}{$\begin{array}{l}\text { S.E. between dates } 0 \cdot 8 \text { ( } 20 \text { D.F.) ; between cultivars } 0 \cdot 6 \text { ( } 72 \text { D.F) ; cultivars within dates } 1 \cdot 6 \text { ( } 72 \text { D.F }) \\
\text { * Data excluded due to poor emergence. }\end{array}$} \\
\hline \multicolumn{7}{|l|}{$1991 / 92$} \\
\hline $15 \mathrm{Nov}$ & 46 & 39 & 49 & 39 & 43 & $32 \cdot 5$ \\
\hline $30 \mathrm{Nov}$ & 55 & 49 & 56 & 50 & 53 & $33 \cdot 4$ \\
\hline $15 \mathrm{Dec}$ & 56 & 53 & 59 & 54 & 55 & $32 \cdot 7$ \\
\hline $30 \mathrm{Dec}$ & 51 & 46 & 52 & 45 & 48 & $31 \cdot 1$ \\
\hline $15 \mathrm{Jan}$ & 46 & 38 & 47 & 41 & 43 & $32 \cdot 3$ \\
\hline $30 \mathrm{Jan}$ & 43 & 37 & 47 & 37 & 41 & $34 \cdot 2$ \\
\hline $15 \mathrm{Feb}$ & 38 & 33 & 41 & 34 & 37 & $35 \cdot 2$ \\
\hline $2 \mathrm{Mar}$ & 36 & 32 & 38 & 32 & 35 & $38 \cdot 7$ \\
\hline Mean (cultivars) & 43 & 44 & 44 & 45 & & \\
\hline
\end{tabular}

holding capacity and organic matter content. Four released West African groundnut cultivars were used in the experiment: 55-437 (Spanish bunch), ICGS 11 (Spanish-type), 47-16 (Virginia runner) and 28-206 (Virginia bunch). The first two cultivars are of short duration, maturing in $<110$ days while the last two are of long duration, maturing in $>120$ days in the normal season. Each cultivar was sown on eight dates separated by 14-day intervals from 15 November 1990 to 2 March 1991 and from 15 November 1991 to 2 March 1992.

Treatments were replicated four times in a randomized block in a split-plot arrangement with sowing dates as main plots, and cultivars as subplots. The subplot was four rows $0.5 \mathrm{~m}$ apart and $6 \mathrm{~m}$ long. Thirty-six kg ha ${ }^{-1} \mathrm{P}_{2} \mathrm{O}_{5}$ as single superphosphate and $16 \mathrm{~kg} \mathrm{ha}^{-1} \mathrm{~N}$ were applied before sowing and $400 \mathrm{~kg}$ $\mathrm{ha}^{-1}$ of gypsum was applied at pod formation. Seeds were sown by hand and the crop was irrigated weekly with $40 \mathrm{~mm}$ of water using overhead sprinkler irrigation in 1990/91 and a linear movement system (Valley Irrigation Inc) in the 1991/92 season.

The plots were observed for flowering and the date when $50 \%$ of the plants had flowered noted. Maturity was decided according to the percentage of pods that had internal staining (Williams \& Drexler 1981). At maturity, the two centre rows of the plot were harvested by hand and dried at $80^{\circ} \mathrm{C}$ for at least $36 \mathrm{~h}$ before pod and haulm dry weights were determined.

The $B$ and $p$ values were estimated using the nondestructive methods described by Williams \& Saxena (1991) and Williams (1992) after the dry matter was adjusted to account for the high energy of kernels. To do this, pod dry matter was multiplied by 1.65 (Duncan et al. 1978); a value reflecting the ratio of carbon production costs of shoot and pod dry matter. Crop growth rates were calculated over the entire crop duration, while the pod growth rates $(P G R)$ were calculated from the time between $50 \%$ flowering and harvest. The $p$ was calculated as $P G R / B$ (Duncan et al. 1978).

The phenological data for days to $50 \%$ flowering from different sowing dates were used to estimate the base temperature $\left(T_{\mathrm{b}}\right)$ for the cultivars used in this experiment $\left(13^{\circ} \mathrm{C}\right)$, there being small differences between cultivars. The optimum temperature $\left(T_{\mathrm{o}}\right)$ and the maximum temperature $\left(T_{\mathrm{m}}\right)$ were not calculated. Thermal times for the phenological phases were computed using the air temperature measured at the meteorological station located c. $500 \mathrm{~m}$ from the 
experimental field and cardinal temperatures of $T_{\mathrm{b}}=$ $13^{\circ}, T_{\mathrm{o}}=30^{\circ}$ and $T_{\mathrm{m}}=40^{\circ} \mathrm{C}$ according to Mohamed et al. (1988). Thermal time expressed as physiological days was based on $24 \mathrm{~h}$ at $T_{\mathrm{o}}$ constituting a physiological day.

The data were subjected to standard analysis of variance, and then the stability analysis concepts of Finlay \& Wilkinson (1963) were used to compare the parameters of the yield determination model for each cultivar across 'environments' as defined by combinations of years and sowing dates.

\section{RESULTS}

Data for cv. 47-16 sown on 30 December 1990 were excluded from the analysis because only $10 \%$ emergence was achieved.

\section{Environment}

The weather (excluding temperature) experienced during the experiments in the two years is presented in Table 1. However, since sowing dates differed so greatly, consideration of the conditions prevailing during various phases of growth is more appropriate. The mean temperatures for the period between sowing and $50 \%$ flowering (vegetative phase) and between flowering and maturity (reproductive phase) were calculated for each sowing date treatment (Fig. 1). The years were similar for the temperatures over the reproductive phase, but 1991/92 was appreciably cooler than 1990/91 during the vegetative phase. Late sowing increased the mean temperatures during both phases by $c .5{ }^{\circ} \mathrm{C}$ relative to the early sowing dates.

\section{Phenology}

All the cultivars took progressively less time to flower (Table 2) and to complete reproductive processes (Table 3) as sowing was delayed from December to March. Time to flowering decreased by nearly 2 weeks in the 1990/91 season as sowing was delayed from December to March while in the 1991/92 season the decrease was close to 3 weeks. Cultivars 47-16 and 28-206 took longest to flower.

Reproductive duration ranged from 72 to 96 days in the 1990/91 season, and from 87 to 111 in the 1991/92 season (Table 3). In 1990/91, groundnut sown in March averaged 104 days to maturity while sowing in the cool months resulted in 137 days to maturity. On the other hand, in 1991/92 maturity was

Table 3. Effect of sowing date on reproductive period (calendar and physiological days) of four groundnut cultivars sown at Sadore, Niger in 1990/91 and 1991/1992

\begin{tabular}{|c|c|c|c|c|c|c|}
\hline \multirow[b]{2}{*}{ Date } & \multicolumn{4}{|c|}{ Cultivar (calendar days) } & \multirow{2}{*}{$\begin{array}{l}\text { Means } \\
\text { for dates }\end{array}$} & \multirow{2}{*}{$\begin{array}{l}\text { Physiological } \\
\text { days }\end{array}$} \\
\hline & $47-16$ & $55-437$ & $28-206$ & ICGS11 & & \\
\hline \multicolumn{7}{|l|}{$1990 / 91$} \\
\hline $15 \mathrm{Nov}$ & 108 & 81 & 107 & 88 & 96 & $89 \cdot 2$ \\
\hline $30 \mathrm{Nov}$ & 92 & 81 & 102 & 91 & 91 & $95 \cdot 0$ \\
\hline $15 \mathrm{Dec}$ & 99 & 73 & 98 & 81 & 88 & $97 \cdot 9$ \\
\hline $30 \mathrm{Dec}$ & * & 65 & 75 & 78 & 73 & $84 \cdot 6$ \\
\hline 15 Jan & 86 & 64 & 83 & 75 & 77 & $90 \cdot 7$ \\
\hline 30 Jan & 89 & 82 & 85 & 83 & 85 & $98 \cdot 6$ \\
\hline $15 \mathrm{Feb}$ & 80 & 60 & 79 & 61 & 70 & $83 \cdot 4$ \\
\hline 2 Mar & 75 & 69 & 74 & 72 & 72 & $83 \cdot 5$ \\
\hline Mean (cultivars) & 88 & 73 & 88 & 78 & & \\
\hline \multicolumn{7}{|c|}{$\begin{array}{l}\text { S.E. between dates } 2.09 \text { ( } 20 \text { D.F.); between cultivars } 1.24 \text { ( } 72 \text { D.F.); cultivars within dates } 3.69 \text { ( } 72 \text { D.F.) } \\
\text { * Data excluded due to poor emergence. }\end{array}$} \\
\hline \multicolumn{7}{|l|}{$1991 / 92$} \\
\hline $15 \mathrm{Nov}$ & 118 & 104 & 115 & 107 & 111 & $95 \cdot 3$ \\
\hline $30 \mathrm{Nov}$ & 109 & 89 & 108 & 102 & 102 & $101 \cdot 4$ \\
\hline $15 \mathrm{Dec}$ & 99 & 97 & 79 & 85 & 90 & $96 \cdot 1$ \\
\hline $30 \mathrm{Dec}$ & 95 & 80 & 95 & 88 & 89 & $97 \cdot 9$ \\
\hline $15 \mathrm{Jan}$ & 98 & 79 & 97 & 84 & 90 & $102 \cdot 6$ \\
\hline $30 \mathrm{Jan}$ & 93 & 74 & 89 & 78 & 84 & $98 \cdot 4$ \\
\hline $15 \mathrm{Feb}$ & 92 & 81 & 89 & 87 & 87 & $102 \cdot 8$ \\
\hline $2 \mathrm{March}$ & 83 & 76 & 81 & 85 & 81 & $94 \cdot 9$ \\
\hline Mean (cultivars) & 98 & 83 & 96 & 90 & & \\
\hline
\end{tabular}


Table 4. Effect of sowing date on pod yield $\left(t h a^{-1}\right)$ of four groundnut cultivars at Sadore, Niger in $1990 / 91$ and $1991 / 1992$

\begin{tabular}{|c|c|c|c|c|c|}
\hline \multirow[b]{2}{*}{ Date } & \multicolumn{4}{|c|}{ Cultivar } & \multirow{2}{*}{$\begin{array}{l}\text { Means } \\
\text { for dates }\end{array}$} \\
\hline & $47-16$ & $55-437$ & $28-206$ & ICGS11 & \\
\hline \multicolumn{6}{|l|}{$1990 / 91$} \\
\hline $15 \mathrm{Nov}$ & $3 \cdot 6$ & $1 \cdot 8$ & $1 \cdot 6$ & $2 \cdot 5$ & $2 \cdot 4$ \\
\hline 30 Nov & $3 \cdot 3$ & $2 \cdot 5$ & $3 \cdot 0$ & $3 \cdot 6$ & $3 \cdot 1$ \\
\hline $15 \mathrm{Dec}$ & $3 \cdot 0$ & $2 \cdot 1$ & $2 \cdot 9$ & $3 \cdot 1$ & $2 \cdot 8$ \\
\hline $30 \mathrm{Dec}$ & $*$ & $2 \cdot 5$ & $2 \cdot 0$ & $2 \cdot 6$ & $2 \cdot 4$ \\
\hline $15 \mathrm{Jan}$ & $3 \cdot 1$ & 1.9 & $2 \cdot 2$ & $2 \cdot 7$ & $2 \cdot 4$ \\
\hline $30 \mathrm{Jan}$ & $2 \cdot 4$ & $2 \cdot 7$ & 1.6 & $2 \cdot 7$ & $2 \cdot 3$ \\
\hline $15 \mathrm{Feb}$ & $1 \cdot 3$ & $1 \cdot 6$ & $0 \cdot 6$ & $1 \cdot 5$ & $1 \cdot 2$ \\
\hline 2 Mar & $1 \cdot 4$ & 1.7 & $0 \cdot 8$ & 1.8 & $1 \cdot 4$ \\
\hline Mean (cultivars) & $2 \cdot 4$ & $2 \cdot 1$ & $1 \cdot 8$ & $2 \cdot 6$ & \\
\hline \multicolumn{6}{|c|}{$\begin{array}{l}\text { S.E. between dates } 0 \cdot 288 \text { ( } 20 \text { D.F.); between cultivars } 0 \cdot 123 \text { ( } 72 \text { D.F.) ; cultivars within dates } 0 \cdot 418 \\
(72 \text { D. F.). } \\
* \text { Data excluded due to poor emergence. }\end{array}$} \\
\hline \multicolumn{6}{|l|}{$1991 / 92$} \\
\hline $15 \mathrm{Nov}$ & $1 \cdot 6$ & 1.6 & $1 \cdot 3$ & $2 \cdot 1$ & $1 \cdot 6$ \\
\hline $30 \mathrm{Nov}$ & $2 \cdot 5$ & 1.5 & $1 \cdot 0$ & $1 \cdot 3$ & $1 \cdot 6$ \\
\hline $15 \mathrm{Dec}$ & 1.6 & $1 \cdot 5$ & $0 \cdot 8$ & $1 \cdot 2$ & $1 \cdot 3$ \\
\hline $30 \mathrm{Dec}$ & $1 \cdot 2$ & 1.0 & $0 \cdot 6$ & $1 \cdot 1$ & 1.0 \\
\hline 15 Jan & $1 \cdot 1$ & $1 \cdot 1$ & $0 \cdot 6$ & 1.0 & $0 \cdot 9$ \\
\hline $30 \mathrm{Jan}$ & $0 \cdot 7$ & $1 \cdot 0$ & $0 \cdot 5$ & $0 \cdot 9$ & $0 \cdot 8$ \\
\hline $15 \mathrm{Feb}$ & $0 \cdot 7$ & $1 \cdot 1$ & $0 \cdot 4$ & $0 \cdot 8$ & $0 \cdot 8$ \\
\hline $2 \mathrm{Mar}$ & $0 \cdot 4$ & $0 \cdot 8$ & $0 \cdot 2$ & $0 \cdot 8$ & $0 \cdot 6$ \\
\hline Mean (cultivars) & $1 \cdot 2$ & $1 \cdot 2$ & $0 \cdot 7$ & $1 \cdot 2$ & \\
\hline \multicolumn{6}{|c|}{$\begin{array}{l}\text { S.E. between dates } 0 \cdot 135 \text { ( } 21 \text { D.F.); between cultivars } 0 \cdot 088 \text { ( } 72 \text { D.F.); cultivars within dates } 0 \cdot 255 \\
\text { ( } 72 \text { D.F.). }\end{array}$} \\
\hline
\end{tabular}

achieved in an average 116 days for the March sowing and 150 days for the November/December sowing.

The variation in the rate of development from sowing to flowering $(1 / f)$, and from $50 \%$ flowering to maturity $\left(1 / D_{r}\right)$ was examined by linear regression against the mean air temperature (Bell et al. $1991 a, b$ ). Mean daily temperature was positively and linearly related to the rate of phenological development from sowing to flowering, and from flowering to maturity in all cultivars. The coefficient of determination values for individual cultivars ranged from 0.74 to $0.97(n=$ 8) for the rate to flowering in 1990/91 and from 0.80 to 0.93 in $1991 / 92$. The relationships between mean daily temperature and the rate of development of pods $\left(100 / D_{\mathrm{r}}\right)$ were less clear and the coefficient of determination values ranged from 0.22 to 0.60 in $1990 / 91$ and from 0.38 to 0.77 in $1991 / 92$. This poorer relationship may be due to the assumptions made about when pod-filling starts, but most of the variation was accounted for by temperature because thermal time estimates for these phases did not differ greatly across sowing dates (Tables 2 and 3 ). However, given that irrigation was at regular intervals, the longer calendar time taken by the early sowing incurred a greater water and management cost than did later sowing.

\section{Pod yield, seed mass and numbers and shelling percentage.}

Both sowing date and cultivars had a significant $(P$ $<0.01)$ effect on pod yield. Pod yield of all cultivars declined by $>50 \%$ in both years from early sowing (mid-November/early December) to later sowing (mid-February/early March) (Table 4). The interaction of cultivar with sowing date was not statistically significant within either year. However, the stability analysis approach combining years and sowing dates shows that the cultivar 55-437 was best when yields were lowest (i.e. late sown and exposed to highest temperature) and lowest when the environment promoted yield (Fig. 2). Haulm yields were less affected by sowing date and only cultivar effects were significant (Table 5). One-hundred-seed mass (size) was highest in the November/December sowing and lowest in the February/March sowing, while threshing percentage only varied slightly across sowing dates (data not shown). 


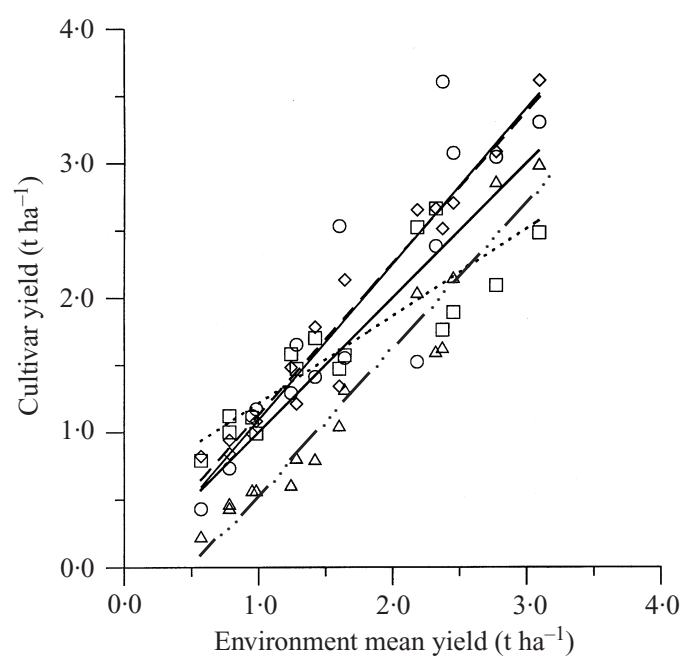

Fig. 2. Pod yield stability across eight dates of sowing at Sadore, Niger; in 1990/91 and 1991/92 for four groundnut cultivars. The lines represent the regression of individual cultivars on the mean of all cultivars in each combination of year and sowing date.

47-16: $\quad \bigcirc \quad y=1 \cdot 159 x-0.069 \quad R^{2}=0.82$

55-437: $\square \cdots \cdots \quad y=0.649 x+0.566 \quad R^{2}=0.78$

28-206: $\triangle \ldots-\ldots \quad y=1.078 x-0.521 \quad R^{2}=0.94$

ICGS11: $\diamond---\quad y=1.127 x+0.003 \quad R^{2}=0.96$

Unit slope -

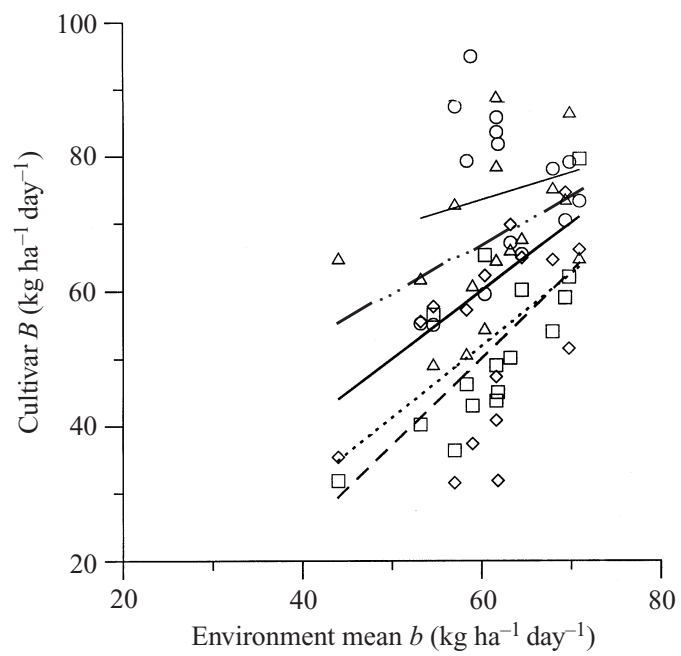

Fig. 3. Stability of crop growth rate across eight dates of sowing at Sadore, Niger; 1990/91 and 1991/92 for four groundnut cultivars. The lines represent the regression of individual cultivars on the mean of all cultivars phase in each combination of year and sowing date.
47-16:
$\bigcirc-y=0 \cdot 406 x+49 \cdot 1$
55-437: $\quad \square \cdots \cdots \quad y=1.286 x-27 \cdot 2$
28-206: $\triangle \ldots-\ldots \quad y=0.707 x+24 \cdot 3 \quad R^{2}=0 \cdot 19$
$R^{2}=0.03$
$R^{2}=0.59$
ICGS11: $\diamond---\quad y=1.063 x-11.9 \quad R^{2}=0.29$

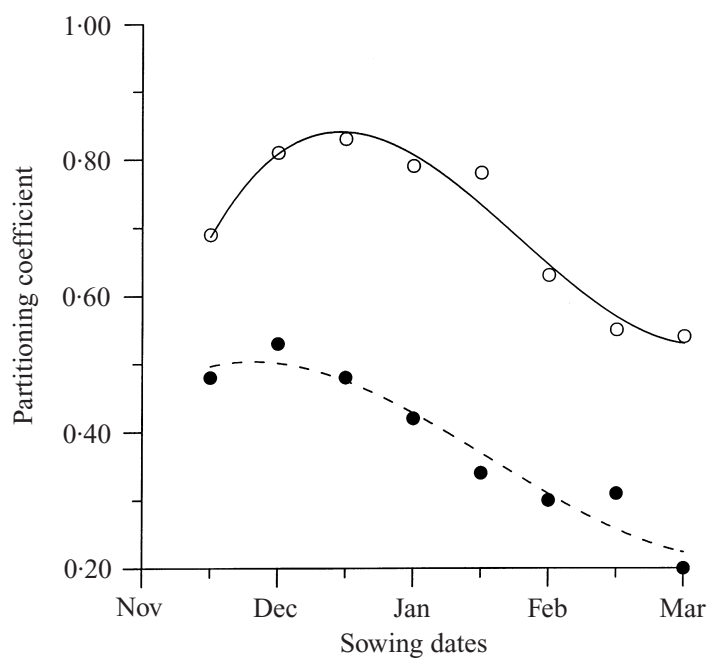

Fig. 4. Average response of partitioning by four groundnut cultivars across eight dates of sowing at Sadore, Niger; 1990/91 ( ○一) and 1991/92 (---).
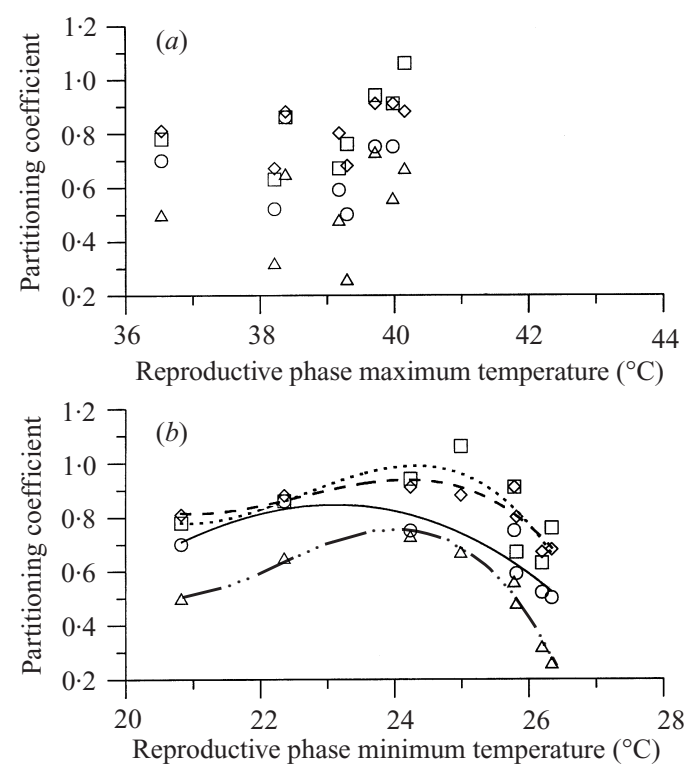

Fig. 5. Relationship between partitioning and (a) maximum and $(b)$ minimum temperature during the pod-filling phase of four groundnut cultivars across eight dates of sowing at Sadore, Niger; 1990/91 and 1991/92. The lines represent the regression of individual cultivars on the mean of all cultivars over this phase in each combination of year and sowing date. 47-16: $\bigcirc-y=-4 \cdot 85+0 \cdot 0886 x+0 \cdot 0243 x^{2}$

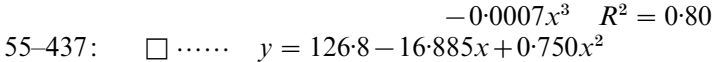

28-206: $\triangle \ldots-\ldots \quad y=126 \cdot 6-17 \cdot 206 x+0 \cdot 778 x^{2}$ $-0.0116 x^{3} \quad R^{2}=0.97$

ICGS11: $\diamond---\quad y=89 \cdot 41-11 \cdot 869 x+0.528 x^{2}$ $-0.0078 x^{3} \quad R^{2}=0.78$ 
Table 5. Effect of sowing date on haulm yield ( $t$ ha $\left.{ }^{-1}\right)$ of four groundnut cultivars sown at Sadore, Niger in 1990/91 and $1991 / 1992$

\begin{tabular}{|c|c|c|c|c|c|}
\hline \multirow[b]{2}{*}{ Date } & \multicolumn{4}{|c|}{ Cultivar } & \multirow{2}{*}{$\begin{array}{l}\text { Means } \\
\text { for dates }\end{array}$} \\
\hline & $47-16$ & $55-437$ & $28-206$ & ICGS11 & \\
\hline \multicolumn{6}{|l|}{$1990 / 91$} \\
\hline $15 \mathrm{Nov}$ & $5 \cdot 75$ & $2 \cdot 25$ & $4 \cdot 75$ & $3 \cdot 00$ & $3 \cdot 94$ \\
\hline 30 Nov & $4 \cdot 25$ & $3 \cdot 23$ & $6 \cdot 00$ & $4 \cdot 00$ & $4 \cdot 38$ \\
\hline $15 \mathrm{Dec}$ & $5 \cdot 25$ & $2 \cdot 75$ & $5 \cdot 25$ & $3 \cdot 50$ & $4 \cdot 19$ \\
\hline $30 \mathrm{Dec}$ & $*$ & $2 \cdot 25$ & $5 \cdot 00$ & $3 \cdot 25$ & $3 \cdot 50$ \\
\hline 15 Jan & $4 \cdot 75$ & $2 \cdot 25$ & $6 \cdot 25$ & $2 \cdot 75$ & $4 \cdot 00$ \\
\hline 30 Jan & $5 \cdot 25$ & $4 \cdot 50$ & $5 \cdot 50$ & $3 \cdot 25$ & $4 \cdot 62$ \\
\hline $15 \mathrm{Feb}$ & $4 \cdot 50$ & $2 \cdot 75$ & $4 \cdot 75$ & $2 \cdot 75$ & $3 \cdot 67$ \\
\hline 2 Mar & $4 \cdot 00$ & $3 \cdot 75$ & $4 \cdot 50$ & $3 \cdot 50$ & $3 \cdot 94$ \\
\hline Mean (cultivars) & $4 \cdot 96$ & $2 \cdot 96$ & $5 \cdot 3$ & $3 \cdot 25$ & \\
\hline \multicolumn{6}{|c|}{$\begin{array}{l}\text { S.E. between dates } 0.353 \text { ( } 20 \text { D.F.); between cultivars } 0.232 \text { ( } 72 \text { D.F.); cultivars within dates } 0.669 \\
\text { ( } 72 \text { D.F.). } \\
\text { * Data excluded due to poor emergence. }\end{array}$} \\
\hline \multicolumn{6}{|l|}{$1991 / 92$} \\
\hline $15 \mathrm{Nov}$ & $3 \cdot 94$ & 1.91 & $4 \cdot 82$ & $2 \cdot 78$ & $3 \cdot 36$ \\
\hline 30 Nov & $6 \cdot 16$ & 1.59 & $6 \cdot 18$ & $1 \cdot 56$ & $3 \cdot 87$ \\
\hline $15 \mathrm{Dec}$ & $7 \cdot 24$ & 1.92 & $4 \cdot 89$ & 1.93 & $4 \cdot 00$ \\
\hline $30 \mathrm{Dec}$ & 4.92 & $1 \cdot 40$ & $5 \cdot 17$ & 1.75 & $3 \cdot 31$ \\
\hline 15 Jan & $6 \cdot 15$ & $2 \cdot 01$ & $6 \cdot 29$ & $2 \cdot 07$ & $4 \cdot 13$ \\
\hline 30 Jan & $6 \cdot 35$ & $2 \cdot 30$ & $4 \cdot 84$ & $2 \cdot 34$ & $3 \cdot 96$ \\
\hline $15 \mathrm{Feb}$ & $5 \cdot 72$ & $2 \cdot 01$ & $6 \cdot 54$ & 1.49 & 3.94 \\
\hline 2 Mar & $5 \cdot 28$ & $3 \cdot 29$ & $6 \cdot 02$ & $2 \cdot 84$ & $4 \cdot 36$ \\
\hline Mean (cultivars) & $5 \cdot 72$ & $2 \cdot 05$ & $5 \cdot 59$ & $2 \cdot 09$ & \\
\hline \multicolumn{6}{|c|}{$\begin{array}{l}\text { S.E. between dates } 0.693 \text { ( } 21 \text { D.F.) ; between cultivars } 0.294 \text { ( } 72 \text { D.F.); cultivars within dates } 1.000 \\
\text { ( } 72 \text { D.F.). }\end{array}$} \\
\hline
\end{tabular}

\section{Crop growth rates and partitioning}

Crop growth rates varied across sowing dates and years (Table 6), with a different pattern of $B$ for each year. In $1990 / 91, B$ was maximized by sowing in January and February, while in $1991 / 92, B$ increased progressively with later sowing. These differences between years in response of $B$ across sowing dates are partly explained by a weak relationship of $B$ with the temperature conditions prevailing in the vegetative phase (coefficient of determination $=0 \cdot 27$ ).

Crop growth rate responses also differed with cultivar, with $B$ of cultivar 55-437 and ICGS 11 being less than that of 28-206 and 47-16 (Fig. 3). The stability analysis for $B$ found that the $B$ of cultivar 47-16 was not related to the 'environmental mean', and that the intercept for 55-437 and ICGS 11 was below the unit slope, but the results were not statistically significant.

Partitioning varied strongly across the years and sowing dates (Table 7), however the response to sowing date within years was consistent (Fig. 4).
Cultivars 55-437 and ICGS 11 had the highest partitioning coefficients at all dates of sowing in the two seasons. The relationship between temperature during the pod-filling phase and partitioning in 1990/91 is shown in Fig. 5. Maximum temperatures during the reproductive phase were not well related to partitioning but there was a good relationship between minimum temperatures and partitioning, with evidence of cultivar differences in partitioning response to mean minimum temperatures. The minimum temperatures of $c .24{ }^{\circ} \mathrm{C}$ were optimum for partitioning.

\section{DISCUSSION}

The results showed that groundnuts may be grown successfully in the post-rainy season in the Sahel. The analysis of the yield-determination model parameters points to areas that require further research to maximize productivity in this cropping opportunity. The instability of production across years, however, remains a cause for concern, and further research should be undertaken at a wider range of sites. 
Table 6. Effect of sowing date on crop growth rate $\left(\mathrm{kg} \mathrm{ha}^{-1}\right.$ day $\left.\mathrm{y}^{-1}\right)$ of four groundnut cultivars sown at Sadore, Niger in 1990/91 and 1991/1992

\begin{tabular}{|c|c|c|c|c|c|}
\hline \multirow[b]{2}{*}{ Date } & \multicolumn{4}{|c|}{ Cultivar } & \multirow{2}{*}{$\begin{array}{l}\text { Means } \\
\text { for dates }\end{array}$} \\
\hline & $47-16$ & $55-437$ & $28-206$ & ICGS11 & \\
\hline \multicolumn{6}{|l|}{$1990 / 91$} \\
\hline $15 \mathrm{Nov}$ & $79 \cdot 2$ & $46 \cdot 2$ & $50 \cdot 7$ & $57 \cdot 2$ & $58 \cdot 4$ \\
\hline $30 \mathrm{Nov}$ & $70 \cdot 3$ & $59 \cdot 0$ & $73 \cdot 5$ & $74 \cdot 5$ & $69 \cdot 3$ \\
\hline $15 \mathrm{Dec}$ & $67 \cdot 0$ & $50 \cdot 1$ & $66 \cdot 0$ & $69 \cdot 7$ & $63 \cdot 3$ \\
\hline $30 \mathrm{Dec}$ & $*$ & $60 \cdot 1$ & $67 \cdot 7$ & $64 \cdot 8$ & $64 \cdot 1$ \\
\hline $15 \mathrm{Jan}$ & $78 \cdot 0$ & $54 \cdot 0$ & $75 \cdot 2$ & $64 \cdot 5$ & $67 \cdot 9$ \\
\hline $30 \mathrm{Jan}$ & $73 \cdot 2$ & $79 \cdot 5$ & $64 \cdot 8$ & $66 \cdot 0$ & $70 \cdot 9$ \\
\hline $15 \mathrm{Feb}$ & $55 \cdot 0$ & $56 \cdot 5$ & $49 \cdot 2$ & $57 \cdot 7$ & $54 \cdot 6$ \\
\hline $2 \mathrm{Mar}$ & $59 \cdot 5$ & $65 \cdot 2$ & $54 \cdot 5$ & $62 \cdot 2$ & $60 \cdot 4$ \\
\hline Mean (cultivars) & $68 \cdot 4$ & $58 \cdot 9$ & $62 \cdot 7$ & $64 \cdot 6$ & \\
\hline \multicolumn{6}{|c|}{$\begin{array}{l}\text { S.E. between date } 5 \cdot 58 \text { ( } 20 \text { D.F.); between cultivars } 3.02 \text { ( } 72 \text { D.F.); cultivars within dates } 9 \cdot 26 \\
\text { ( } 72 \text { D.F.). } \\
\text { * Data excluded due to poor emergence. }\end{array}$} \\
\hline \multicolumn{6}{|l|}{$1991 / 92$} \\
\hline $15 \mathrm{Nov}$ & $55 \cdot 2$ & $40 \cdot 2$ & $61 \cdot 8$ & $55 \cdot 5$ & $53 \cdot 2$ \\
\hline $30 \mathrm{Nov}$ & $87 \cdot 3$ & $36 \cdot 3$ & $72 \cdot 8$ & $31 \cdot 5$ & $56 \cdot 9$ \\
\hline $15 \mathrm{Dec}$ & $94 \cdot 8$ & $43 \cdot 0$ & $60 \cdot 8$ & $37 \cdot 3$ & $58 \cdot 9$ \\
\hline $30 \mathrm{Dec}$ & $69 \cdot 0$ & $31 \cdot 8$ & $64 \cdot 8$ & $35 \cdot 3$ & $50 \cdot 2$ \\
\hline 15 Jan & $83 \cdot 5$ & $43 \cdot 7$ & $78 \cdot 5$ & $40 \cdot 8$ & $61 \cdot 6$ \\
\hline $30 \mathrm{Jan}$ & $85 \cdot 7$ & $49 \cdot 0$ & $64 \cdot 5$ & $47 \cdot 3$ & $61 \cdot 6$ \\
\hline $15 \mathrm{Feb}$ & $81 \cdot 7$ & $45 \cdot 0$ & $88 \cdot 8$ & $31 \cdot 8$ & $61 \cdot 8$ \\
\hline $2 \mathrm{Mar}$ & $79 \cdot 0$ & $62 \cdot 0$ & $86 \cdot 5$ & $51 \cdot 5$ & $69 \cdot 7$ \\
\hline Mean (cultivars) & $79 \cdot 5$ & $43 \cdot 9$ & $72 \cdot 3$ & $41 \cdot 3$ & \\
\hline \multicolumn{6}{|c|}{$\begin{array}{l}\text { S.E. between dates } 10.09 \text { ( } 21 \text { D.F.); between cultivars } 3.99 \text { ( } 72 \text { D.F.); cultivars within dates } 14.04 \\
\text { ( } 72 \text { D.F.). }\end{array}$} \\
\hline
\end{tabular}

Partitioning was clearly the major cause of yield differences between the two years. However, the source of this difference was not obvious from the data and other observations. Comparison of the weather data for the two years shows that 1991/92 (with the poorest partitioning) had a cooler vegetative phase, but it is not clear why the results for a given temperature should be so different. Deficiency in calcium supply for pod nutrition can cause variations in partitioning (Hartmond et al. 1994) but, since shelling percentage was similar for the two years, this source of variation can be discounted. Variations in the irrigation can also be discounted as a source of variation in partitioning between years, since the primary productivity was very similar for the two experiments $\left(63.6\right.$ v. $\left.59 \cdot 2 \mathrm{~kg}^{-1} \mathrm{ha}^{-1} \mathrm{day}^{-1}\right)$.

Sowing date responses were consistent across years, yields of all cultivars being highest in the November/ December sowings, these being at least $50 \%$ more than those obtained from March sowings. These differences were mainly due to the progressive decrease in partitioning with sowings later than early December (Fig. 4). This decline in partitioning is closely associated with the mean minimum temperature during the reproductive phase of crop growth. The importance of the minimum temperature rather than the maximum temperature may be explained by the fact that flowering occurs during the night and early morning and pollen viability is sensitive to temperatures $>33{ }^{\circ} \mathrm{C}$ (De Beer 1963). These results differ from those of Williams et al. (1975) and Young et al. (1979), who found that pod yield was optimized at temperatures below the general optimum. Stability analysis of partitioning showed no cultivar interactions.

In both years, $B$ increased with later sowing from November to February or March but the response patterns from cultivars were different. Some of the differences in response may be attributed to the temperatures during the vegetative phase but there was still considerable instability in the response of $B$ to sowing date for unidentified reasons. However, resource capture models, and the fact that the later maturing lines (47-16 and 28-206) had the higher $B$, suggest that these differences are likely to be associated with canopy development; therefore, research to find the sources of this instability seem particularly appropriate.

Cultivars differed in their yield, with both $p$ differences and $B$ variations being significant sources 
Table 7. Effect of sowing date on partitioning of growth to reproductive structures by four groundnut cultivars sown at Sadore, Niger in 1990/91 and 1991/1992

\begin{tabular}{|c|c|c|c|c|c|}
\hline \multirow[b]{2}{*}{ Date } & \multicolumn{4}{|c|}{ Cultivar } & \multirow{2}{*}{$\begin{array}{l}\text { Means } \\
\text { for dates }\end{array}$} \\
\hline & $47-16$ & $55-437$ & 28-206 & ICGS11 & \\
\hline \multicolumn{6}{|l|}{$1990 / 91$} \\
\hline $15 \mathrm{Nov}$ & $0 \cdot 70$ & $0 \cdot 78$ & $0 \cdot 50$ & $0 \cdot 81$ & $0 \cdot 69$ \\
\hline 30 Nov & $0 \cdot 86$ & $0 \cdot 86$ & $0 \cdot 65$ & $0 \cdot 88$ & $0 \cdot 81$ \\
\hline $15 \mathrm{Dec}$ & 0.75 & 0.94 & 0.73 & $0 \cdot 91$ & $0 \cdot 83$ \\
\hline $30 \mathrm{Dec}$ & $*$ & 1.06 & $0 \cdot 67$ & $0 \cdot 88$ & $0 \cdot 87$ \\
\hline $15 \mathrm{Jan}$ & $0 \cdot 75$ & $0 \cdot 91$ & $0 \cdot 56$ & $0 \cdot 91$ & $0 \cdot 78$ \\
\hline $30 \mathrm{Jan}$ & $0 \cdot 59$ & $0 \cdot 67$ & $0 \cdot 48$ & $0 \cdot 80$ & $0 \cdot 63$ \\
\hline $15 \mathrm{Feb}$ & $0 \cdot 50$ & $0 \cdot 76$ & $0 \cdot 26$ & $0 \cdot 68$ & $0 \cdot 55$ \\
\hline $2 \mathrm{Mar}$ & 0.52 & $0 \cdot 63$ & $0 \cdot 32$ & $0 \cdot 67$ & 0.54 \\
\hline Mean (cultivars) & 0.65 & $0 \cdot 82$ & $0 \cdot 52$ & $0 \cdot 82$ & \\
\hline \multicolumn{6}{|c|}{$\begin{array}{l}\text { S.E. between dates } 0 \cdot 038 \text { ( } 20 \text { D.F.); between cultivars } 0.022 \text { ( } 72 \text { D.F.); cultivars within dates } 0 \cdot 065 \\
\text { ( } 72 \text { D.F.). } \\
\text { * Data excluded due to poor emergence. }\end{array}$} \\
\hline \multicolumn{6}{|l|}{$1991 / 92$} \\
\hline $15 \mathrm{Nov}$ & $0 \cdot 38$ & $0 \cdot 63$ & $0 \cdot 31$ & $0 \cdot 60$ & $0 \cdot 48$ \\
\hline $30 \mathrm{Nov}$ & $0 \cdot 44$ & $0 \cdot 77$ & $0 \cdot 23$ & 0.69 & 0.53 \\
\hline $15 \mathrm{Dec}$ & $0 \cdot 29$ & $0 \cdot 73$ & $0 \cdot 25$ & $0 \cdot 63$ & $0 \cdot 48$ \\
\hline $30 \mathrm{Dec}$ & $0 \cdot 30$ & $0 \cdot 65$ & $0 \cdot 15$ & $0 \cdot 56$ & $0 \cdot 42$ \\
\hline 15 Jan & $0 \cdot 22$ & 0.53 & $0 \cdot 12$ & $0 \cdot 48$ & $0 \cdot 34$ \\
\hline $30 \mathrm{Jan}$ & $0 \cdot 15$ & $0 \cdot 47$ & $0 \cdot 16$ & $0 \cdot 42$ & $0 \cdot 30$ \\
\hline $15 \mathrm{Feb}$ & $0 \cdot 16$ & $0 \cdot 51$ & 0.09 & $0 \cdot 49$ & $0 \cdot 31$ \\
\hline $2 \mathrm{Mar}$ & $0 \cdot 10$ & $0 \cdot 33$ & $0 \cdot 05$ & $0 \cdot 30$ & $0 \cdot 20$ \\
\hline Mean (cultivars) & $0 \cdot 26$ & $0 \cdot 58$ & $0 \cdot 17$ & $0 \cdot 52$ & \\
\hline \multicolumn{6}{|c|}{$\begin{array}{l}\text { S.E. between dates } 0.037 \text { ( } 21 \text { D.F.); between cultivars } 0 \cdot 018 \text { ( } 72 \text { D.F.); cultivars within dates } 0 \cdot 058 \\
\text { ( } 72 \text { D.F.). }\end{array}$} \\
\hline
\end{tabular}

of pod yield variation. The cultivars 55-437 and ICGS11 compensated for lower growth rates by having high partitioning. The different responses of cultivars across sowing date and year for B (Fig. 3), suggests that canopy development of the shorter duration Spanish types was more sensitive to low temperatures than was that of the Virginia cultivars. Two factors could have acted to create this effect, without differential sensitivity of cultivars to low temperature. First, the shorter time before flowering would have limited the canopy development before flowering commenced and, second, the differences in partitioning would have resulted in different amounts of canopy growth during the reproductive phase. Thus, although sowing in the cooler months maximized $p$, it also limited canopy development (particularly so for the high partitioning and early flowering cultivars) so that counteracting yield determining forces came into play. The lack of sensitivity displayed by cv. 47-16 (runner habit) which could have higher $B$ when other cultivars had low $B$, supports the idea that spacing and population changes are needed to ensure complete light capture.
The lack of a strong interaction between sowing date and cultivar for yield within years may be taken to suggest that choice of cultivar can be made without considering when production will occur. The lack of interaction occurred because the variations in $B$ compensated for the changes in $p$. Since the evidence suggests that $B$ can be manipulated by appropriate management to maximize energy interception by the crop, this would suggest that yields will be maximized by the correct combination of cultivar and management. Late sowing should use those cultivars with $p$ least affected by temperature (these results and Greenberg et al. 1992).

In this study, average daily temperature during kernel development (Fig. 1) was generally above the ranges reported as optimum (Williams et al. 1975; Young et al. 1979) and seed size generally declined with later sowings, which experienced higher temperatures (data not shown). Although there would be wide system implications to the idea, the use of short season cultivars in the normal cropping season could allow sowings earlier than tested in these experiments. This could be more desirable still, since 
canopy and fruit initiation would occur before temperatures became limiting to canopy and fruit development and seed sizes would be maximized.

In the Sudano-Sahelian zone with the existing rainy season-based crop system, it would be desirable to sow irrigated groundnuts in November. This would provide sufficient time for the crop to be harvested before the onset of the high temperatures in March, thus avoiding extreme atmospheric aridity and very warm temperatures. As such it is probable, given the responses observed in the present study, that a phenologically adapted dry-season cultivar would flower in c. 35 days and mature c. 136 days from sowing.

\section{REFERENCES}

Bell, M. J., Shorter, R. \& Mayer, R. (1991a). Cultivar and environmental effects on growth and development of peanuts (Arachis hypogaea L.). I. Emergence and flowering. Field Crops Research 27, 17-33.

Bell, M. J., Shorter, R. \& Mayer, R. (1991b). Cultivar and environmental effects on growth and development of peanuts (Arachis hypogaea L.). II. Reproductive development. Field Crops Research 27, 35-49.

De BEER, J.F. (1963). Influences of temperature on Arachis hypogaea $L$. with special reference to its pollen viability. Doctoral dissertation, Wageningen Agricultural University, The Netherlands.

Duncan, W. G., McCloud, D. E., McGraw, R. L. \& Boote, K. J. (1978). Physiological aspects of peanut yield improvement. Crop Science 18, 1015-1020.

Finlay, K. W. \& WiLKinson, G. N. (1963). The analysis of adaptation in a plant-breeding programme. Australian Journal of Agricultural Research 14, 742-754.

Greenberg, D. C., Williams, J.H. \& Ndunguru, B. J. (1992). Differences in yield determining processes of groundnut (Arachis hypogaea L.) genotypes in varied drought environments. Annals of Applied Biology 120, 557-566.

Hartmond, U., Williams, J.H. \& Lenz, F. (1994). The influence of plant growth habit on calcium nutrition of groundnut (Arachis hypogaea L.) pods. Plant and Soil 160, 113-118.

Mohamed, H.A., Clark, J.A. \& Ong, C.K. (1988). Genotypic differences in the temperature responses of tropical crops. I. Germination characteristics of groundnut (Arachis hypogaea L.) and pearl millet (Pennisetum typhoides S. \& H.). Journal of Experimental Botany 39, $1121-1128$.

Monteith, J.L. (1990). Conservative behaviour in the response of crops to water and light. In Theoretical
Production Ecology: Reflections and Prospects (Eds R. Rabbinge, J. Goudriaan, H. van Keulen, F. W. T. Penning de Vries \& H. H. van Laar), pp. 3-16. Wageningen, The Netherlands: PUDOC.

ONG, C.K. (1986). Agroclimatological factors affecting phenology of groundnut. In Agrometeorology of Groundnut (Eds M. V. K. Sivakumar, S. M. Virmani \& S. R. Beckerman), pp. 115-125. Patancheru, India: International Crops Research Institute for the Semi-Arid Tropics.

Williams, E. J. \& DreXler, J. S. (1981). A non-destructive method for determining peanut pod maturity. Peanut Science 8, 134-141.

WiLliams, J. H. (1992). Concepts for the application of crop physiological models to crop breeding. In Groundnut - A Global Perspective: Proceedings of an International Workshop (Ed. S. N. Nigam), pp. 345-352. Patancheru, India: ICRISAT.

Williams, J. H. \& Saxena, N.P. (1991). The use of nondestructive measurement and physiological models of yield determination to investigate factors determining differences in seed yield between genotypes of 'desi' chickpeas (Cicer arietum). Annals of Applied Biology 119, $105-112$.

Williams, J. H., Wilson, J. H. H. \& Bate, G. C. (1975). The growth of groundnuts (Arachis hypogaea L. cv. Makulu Red) at three altitudes in Rhodesia. Rhodesian Journal of Agricultural Research 13, 33-44.

Williams, J. H., Hildebrand, G. L. \& Tattersfield, J. R. (1978). The effect of weather and genotype $\times$ environment interaction on the yields of groundnuts (Arachis hypogaea L.). Rhodesian Journal of Agricultural Research 16, 193-204.

Young, J. H., Cox, F. R. \& Martin, C. K. (1979). A peanut growth and development model. Peanut Science 6, 27-35. 